\title{
絹精練廢液利用に關する研究
}

農學士角 替利策

(大正十五种四月九日受理)

\begin{abstract}
緒㝘
絹は甲斐絹或は御召し等の如く絲に於て精練せられ後織物こせらるつ加或仿旸
\end{abstract} 二重縮緬等の如く製織後に於て精練せらる〉か何れにしても一度精練工程を通過 せざるバからざる事何人る熟知する所なり該情練工程は要するに絹䋐維の外側を 抱圍する一種の蛋白質即ら絹ゴム質(Sericin)の全部或は一部を除去する工程にし て現今最も普通に使用せらるつ方法は石鹼即ち所謂 Marseilles soap に上りて行 はるつものなり石簽により絹を精練する場合に告成せらるつ廢液即ち絹練廢液は 多量刀石䶨及 Sericin 支含有するに拘らず之が利用方法の工業的に成切せるもの ある早見す

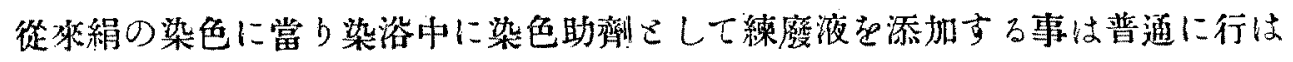
るつ處なれざを其分量たるア甚げ僅かにして特に本邦絹業の如く幼稚にして輸出 絹の大部分は精練せられたるま〉無染色にて輸出せらるつに於ては練廢液の利用 る亦極めて少量にて大部分は之放廢轵する外なき狀態なり然るに最近數年間の輸 出絹織物の數量より推測するに每年輸出絹のみの精練より廢出せらるる練廢液中 の石簽約 20 萬宣 Sericin。亦略同量に達す心し若し之が經濟的利用力法を發見

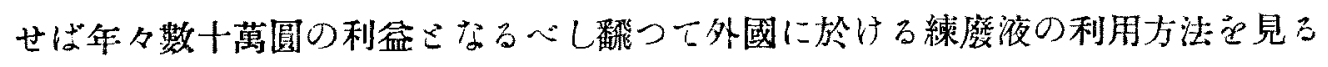
に之ゔ䂨究に着手せるは十九世紀の終っ 10 年間 ${ }^{(1)}$ 以降にして當時勞賃の撥貴さ

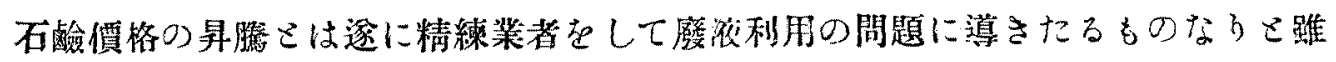
る未だ工業的に成功せるものあるを聞かず本邦に於ては大正 7,8 年頃之が利服の 方法發明(2)せられ一時實施せられてる事あるしこ踓も遂に大成するに到らず最 近獨逸國 Krefeldに於ても喥液上り脂肪酸回收の工場設立 ${ }^{(3)}$ せられたりを踓も中 止の止むなきに到れりを聞く余は大正十一年以爽之が利用の方法に付き研究やな し一二の方法を得てりょりて丝に報告せんさす 


\section{2. 文献}

精練廢液（Boiled off liquor，Bastseife）の利用に關する方法に付き交狱に徵す ろに大別して 3 こなす事得心し即ち下の如し

(a)、精練廢液より脂肪酸を回收し更に石龢に還元せんこするもの

(b)、脂肪酸さScricin き尼回收し前者は石醶に後者は肥料さなさんさする もの

(c)、脂肪酸さScricin こを利用して電氣絕緣體を製造せんこするもの

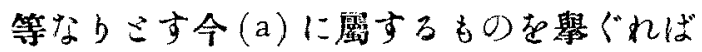

I. Silbermann ${ }^{(4)}$ 氏法は Boiled off liquor に監化石灰或は石灰乳走加へて石灰

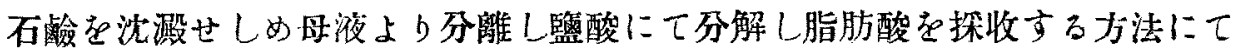
該脂肪酸は石獣に還元する事を得へし

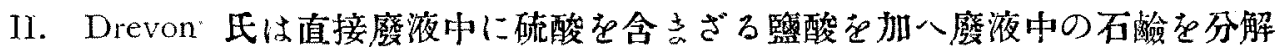
して脂肪酸走探收す

III. Gianoli 氏は酸性ミなしたる硫酸鐵にて廢液中の遊離アルカリを中和し同

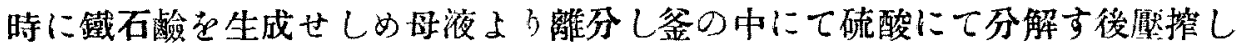
七脂肪酸定探收方 ${ }^{(6}$

IV. Taylor 氏は鹽素死斯を廢液中に通して脂肪酸を漂白しつっ同時に分離せし $t(7)(7)$

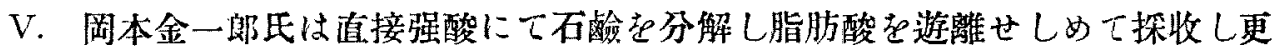
に石䲓に還元す

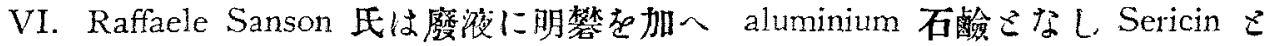
共に母液よ气分離し監酸にて分解し水にて惹沸し Sericin を除き脂肪酸を精 㐮す ${ }^{(9)}$

\section{（b）に屬する方法}

I. 大正元年阿久津隆三氏は先つ石灰乳次て硫酸を加一脂肪酸さ硫酸石灰飞 Sericinこの混合物を沈澱せしめ母液より分離し壓㩁或は溶剂走使用して Extraction 专行ひ脂肪酸支探收す(11)

II. Ferdinand 氏の報告によれば廢液を强酸にて處理すれば脂肪酸を Sericin この混合物は直に分離す此雨者の分離结壓竅法或は浸出法によりて篇し得心きき

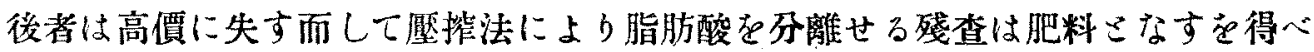


III. 西田博太郎比の近世色染法第二編に依れば精維廢液邑强酸にて處理し脂肪

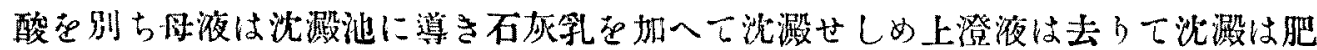
料こなす(12)

(c) に鹰する方法

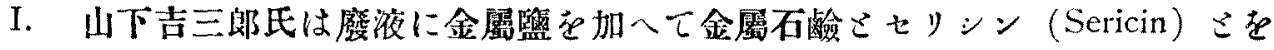
吸着して甘液より分嚾せしめ此兩者の電氯に對する絕緣性を利用して Insulator を作る方法を發明す ${ }^{(13)}$ 而して金屬石畧汃 Insulator なる事は理化學研究所の試驗 に依りて明かなる(1)

\section{第 一 章}

交献に對する實驗的比較

以上の文献を化學的方法上より分類すれば 3 こ感す事る得へしし

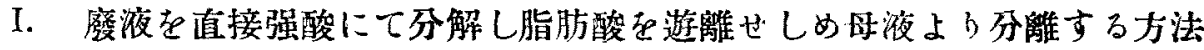

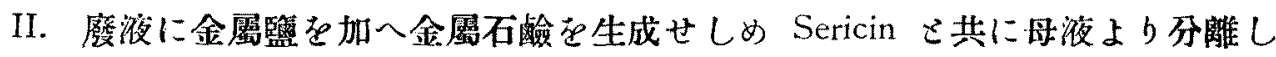
後强酸にて分解し脂肪酸及 Sericin の混合物を得然万後 (a) 水にて者沸し Sericin

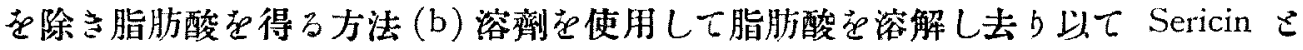
分離する方法 (c) 壓接して脂肪酸を浸出し Sericin こ分離する方法なり

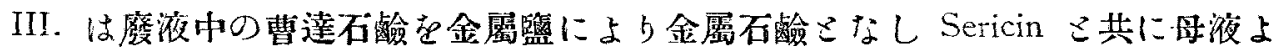

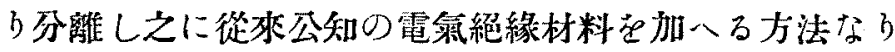

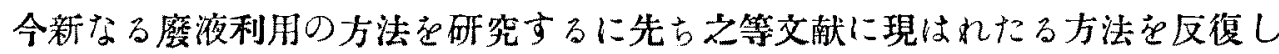

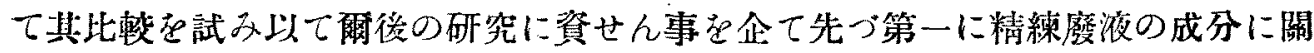
する斫究を雼せり

\section{精練廢液の成分に關する研究}

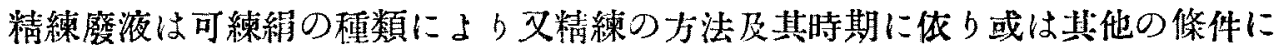
より一定の成劦を有するるのにあらす Silbermann 氏

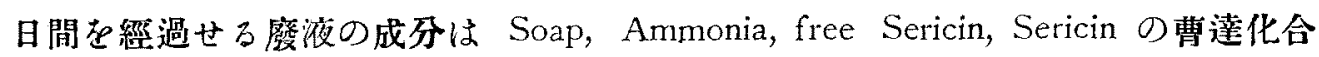
物 Oxysericin 及遊離脂肪なりこ云ふHurst ${ }^{(16)}$ 氏の分折に上れば

$\begin{array}{ll}\text { Sp. gr. } & 1.002 \\ \text { Soap. } & 0.6 \% \\ \text { Sericin } & 0.9 \%\end{array}$


$\mathrm{H}_{2} \mathrm{O}$

$98.5 \%$

なりこ云ふメ Ferdinand Schöller ${ }^{(1)}$ 氏の報告に依扎ば廢液中の石畧分は時に2〜3 に及ふ事ありさ又 Conklin ${ }^{(18)}$ 氏は絹を泡練りする場合には炭酸曹達、燐酸曹澾、 及醋酸曹達等を加へる事意報告せるが故に如斯き場合の廢液中に之れ等の物質の

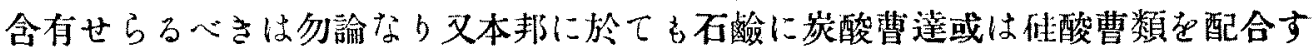
る事は普通なり余か＼cjkstart生絲检查所に於ける練減检查の際生成せられたる廢液に付き 分析せる結果は下の如し

$\begin{array}{ll}\text { Sp. gr. } & 1.010 \\ \text { Soap. } & 1.119 \% \\ \text { Free fatty acids } & 0.143 " \\ \text { Sericin } & 0.316 "\end{array}$

又絹織物の製織に當りて油類，糊類，防府劑等さ使用するものにして之等の物 質か;廢液中に含有せらるっは當然なり要之するに塺液中に於て回收の價值わるも のは脂肪酸及 Sericinの外に出ざるべし

今上記の組成を有せる廢液につき文献に現はれたる方法につき比較試醶号施行

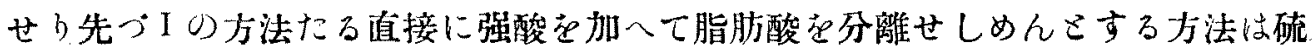
酸及鹽酸を使用するも脂肪酸の畨をして液面に浮遊せしむる事は容易にはすらず 之れ含有せるるっSericin の保護 Colloid の性質に起因するものなるへし又分離 せられたる脂肪酸の層は必ず一部の Sericin 走含有するが故に純粹なる且無色の 製品在得る事不可能なり㖇本方法は Sericin を回收し得ざる欠點あり

次にIIの力法の實驗をなにす當り金屬石鹼の Sericinに對する凝聚力を檢定せ

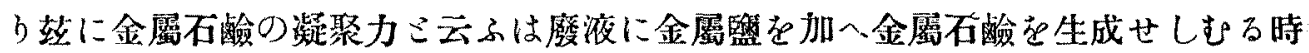
Sericin をる四着して沈澱するものにして該分量は金屬石畧の種類に依り大なる

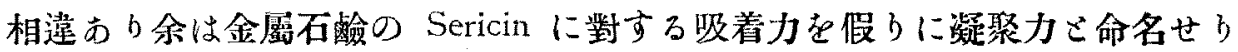

前述の如く㢸液中の Sericin 所含量は $0.316 \%$ る事既に明かなるる以て該廢 液一定量宛を探り之に硫酸銅，醋酸鉛，明礬，監化石灰等を別々に加へて各々金

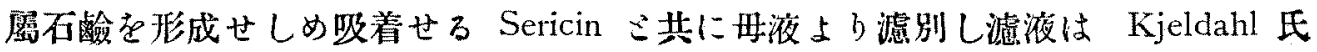

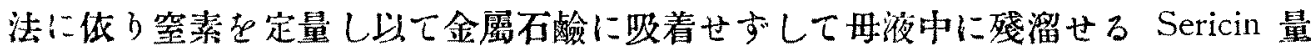
を算出し之を Sericin 全量より控除し以て金屬石鹼に吸着せる Sericin の量を算 出せ b該結果は下の如し 


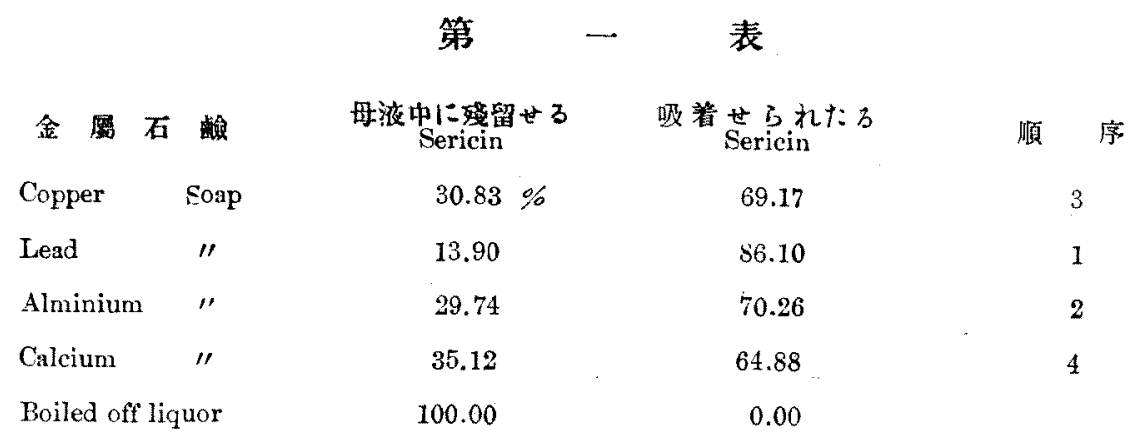

本成績に徵すれば鉛石䨐の凝聚力最も大なるを知るべし次に金屬石鹼に吸着せ られたる Sericin を探收する方法に附き陚驗せり即ち金屬石畧さSericinこの混合 物に水を加入㹂挷しつっ加温して Sericin 点溶解せしめ以て不溶解性なる金屬石 畧走分離する方法及水の代りに稀薄なる节性曹達を使用して Sericin を溶解し去 る方法並加壓釜中にて加壓熱湯に依り Sericin 塎解せん巳する方法の三者に附 き實驗せるに何札も完全に Sericin を溶解し去る(金屬石鹼を分解する事なしに) 事能はざらき而して Sericin の水溶液より Sericin を回收せん篇め酸を加へたる

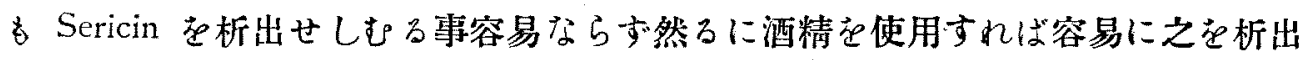
せしむる事走得さ踓も高價に失するね以て問題さならず

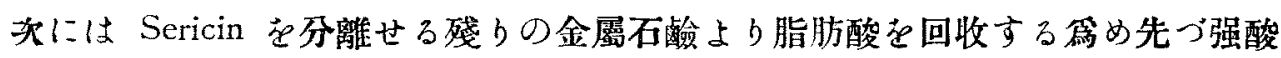
を以て $\left(\mathrm{SO}_{4} \mathrm{H}_{2}\right.$ ，及 $\mathrm{ClH}$ ）金屬石襝を分解したれごる前工程たるSericin の分離 不完全なる篇め之物の一部は脂肪酸中に入り隶り從つて純粹なる脂肪酸を得る事

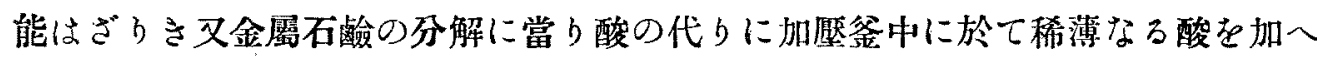
壓力さ高盓さを試み $\left(121^{\circ} \mathrm{C}, 2\right.$ 氣壓) たれでも分解生成物は Sericin を混入し前 方法乏同樣純粹なる脂肪酸を得万事能はざりき

次に廢液に直接强酸を加へて生する脂肪酸さSericinこの混合物を册夜上り分 離し是控法に依り脂肪酸を絞出せるに之亦不完全にして殘留せる Sericin 中には 倘約 $25 \% 0$ 脂肪酸を含有せり又脂肪酸さSericin この混合物上り有機溶劑例へ ば石油ェーテルに依り脂肪酸を溶出する方法は装作甚だ容易に且完全なりこ踓も 高價に失方而して Sericin 䍃加壓熱湯(Autoclave) 中にてに依り溶解せしむる方法 も脂肪酸の純粹なるものは得難し上上の賽驗に徵し文献の方法は何れも理想的な るものこ認め難し 


\section{第 二 章}

精練廢液上り殺菌劑の裂造法

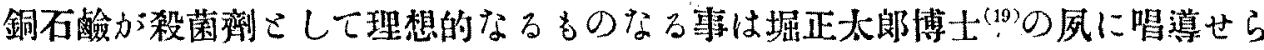

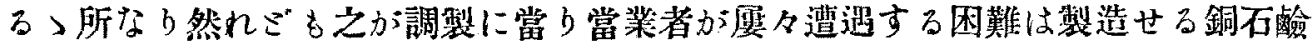
液が洮澱して乳狀態を形成せざるここなり該原因は教多するへししで踓も主たるも のは使用せる水の硬度高き事さ石殓支構成せる脂肪酸の種類と並びに硫酸銅に對 する石㑼の分量こにして何れも化學者の手を煩はすに非らざれば制別し能はざる 原因にして當業者が之落製造するに當り不安を感ずる所大なれごも一々化學分析

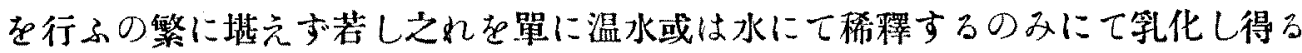

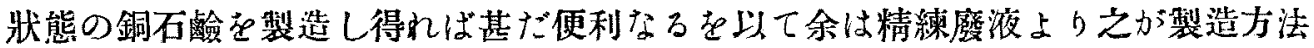

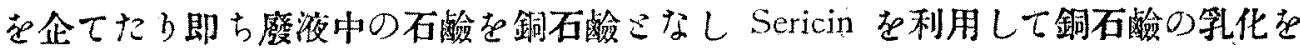
助けんこするものなる

絹精練廢液に（冷却せる後にても差支無し暖き内なれば一層可なり）硫酸銅を 過剩に加ふる時は銅石畧僉は沈澱す此の時冊液のSericinの約70\%は吸着して沈澱 す此物は極めて容易に布にて滤過せらる水に不溶解なる方以て乳化の手段を講せ ざれば之のまつにては噴霧器を以て作物に撒布する事能はず然れごもこに普通 の乳化劑たるロート油，(Turky red oil) アラビヤゴム，寒天，ゼラチン，加里石 畧登趹或は Twitscher reagent ${ }^{(21)}$ 等を加へる時は容易に乳化する事を得へし例へば Turky red oil を使用する場合は廢液より沈澱せしめたる銅石畧こ Sericinこの混 合物（70\%の水を含有するもの）に對して $5 \%$ を加へ能く練る時は任意の温湯或 は水にて乳化し得るものこなる而して如斯き裂劑は略 $2.5 \%$ 窒素を含有せり

前に躰に記述せる如く虔液の成分は種々なる條件に上り相違し一定なるものに あらす從つて或る種類の廢液にありては硫酸銅点過剩に加ふるこる沈澱走生ずる 事不完全にして滤過し能はざる場合あり其原因学探求せるに次の結果を得たり即 ち (a) 精練廢液中にSericinの分量過少なる時 (b) 炭酸曹達の量過大なる場合及 （c）石殓を構せる脂肪酸が大部分不能和なる場合等なり而して (c)なる場合は銅 石鹼の沈澱不完全なるにはあらすして沈澱せるものが粘着性過大にして容器の壁 或蚁滤過用の布に附着して分離困蜼なるものなら

如斯き場合に於て之適當に處理せんきするには先ゔ(a)の場合は他のSericin に富吉廢液補ふか或は大豆汁（ゴジル）の如き蛋白質を少量に添加すれば甚だ 
容易に分離し得へく(b)の場合は新に少量の石醶を添加するか炭酸曹羍を多量に 含有せざる他の廢液を補ふへくく又(c)の場合は牛脂より製せる石醶の如く䳌和脂

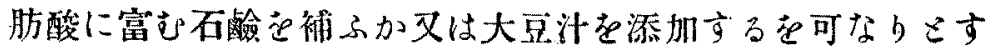

本万法にて製造せられたる銅石鹼は次の如き特徴を有す

1. 任意量の温晹或は水々以て乳狀化し得る事

2. 獨逸硬度 20 度以下の硬水は使用に堪元る事又 $1 \%$ 以下の食鹽水にても使用 し得る事

3. 四着性大なるSericin 余有するを以て能く作物に附着するを以て使用後降 雨に會するも洗ひ流去られ難き事

4. Sericinは窒素它含有するを以て固場に入る時は肥効を呈すべき事

5。廢物より整造するものなるを以て安價に製せらるつ事

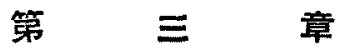

精練廢液上り脂肪酸及 Sericin の回收法

精練廢液中の脂肪酸の大部分は石铪の形態にして遊離せる脂肪酸は少量なり前 々章に於て悓に記載せる如く廢液に金屬監を加了る時最も多量の Sericin 记凝聚

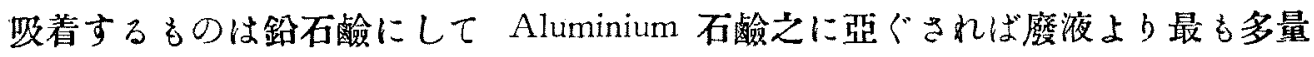

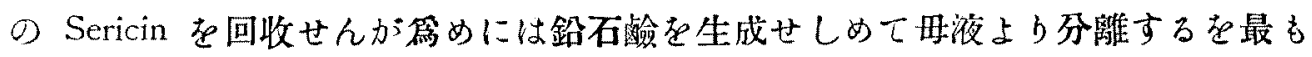

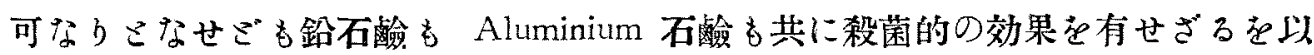
て夏期に於ては Sericin を含む金屬石畧が鹰敗する恐机ありされぱ殺菌力の强き

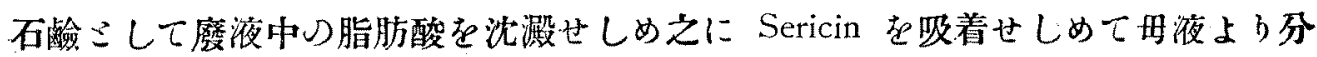
離するを便利なりさなす即ち廢液に硫酸銅を過剩に加へて曹達石鹼は之を銅石畧 に替へ脂肪酸（遊離せる）及び Sericin 它吸着せしめて沈搌せしめ睤液より分離 する距以脂肪酸及 Sericin 回收法の第一着手さなす

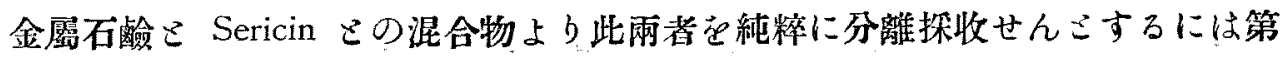
一章の實驗に於て明かなる如く困難なる問題なるを以て先つ强酸 $\left(\mathrm{SO}_{4} \mathrm{H}_{2}, \mathrm{ClH}\right.$ 等)

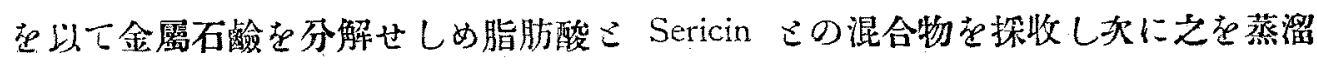

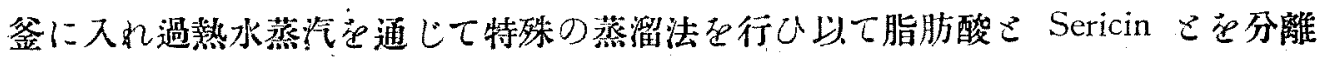
する方法や試みたり

落に特殊蒸溜法こ云ふは蒸溜嚗中に絕えす過熱水蒸汽を通しつつ蒸溜を行ふの

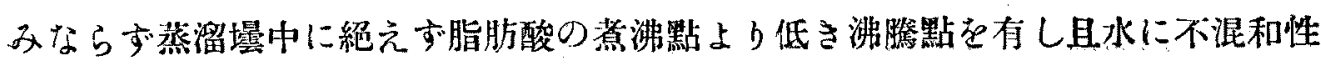


なる有機溶劑例へば Toluene 四監化炭素Xylene 等を滴下しつつ蒸溜するものな り如斯き蒸溜法に依る時は脂肪酸は過热水蒸溜汽蒸溜の場合に比して $30-50^{\circ} \mathrm{C}$ の蒸溜温度の低下するを見るものなり余は前記の有機溶劑に對し蒸溜媒助劑こ命

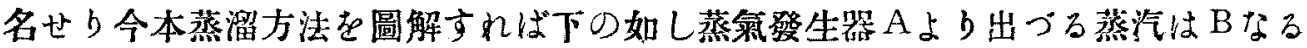

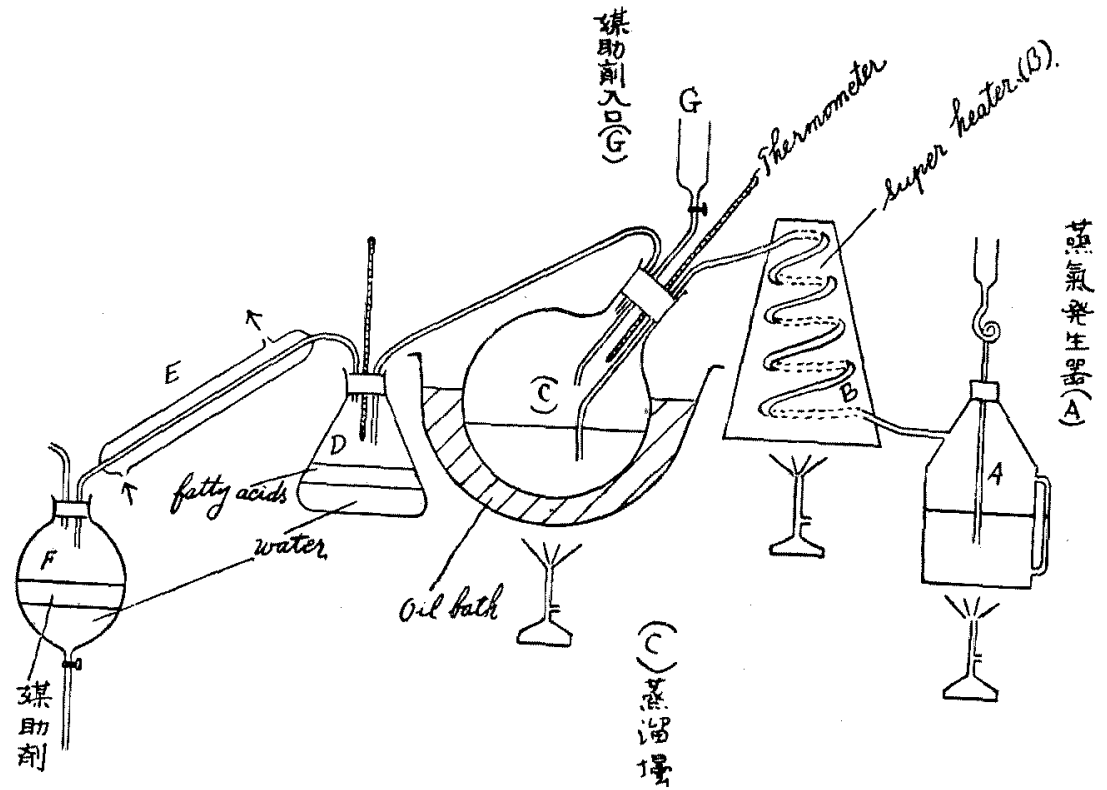

蛇管を通過する間に過苝せられてCなる蒸溜嚗中に入るCには豫め蒸溜せらる心 き脂肪酸及 Sericin の混合物る容れ Oil Bath中に納めて徐々に加䕀しB上り來

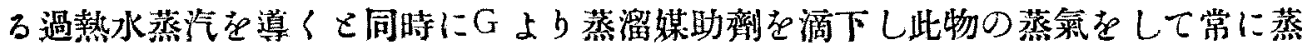
溜嚗中に佨和せしさ站に於て脂肪酸の蒸汽は水及媒助劑の蒸汽こ共に溜出しDな る第一の受器に集る令媒助劑こして Toluene 在使用する場合の例に付きて遮心 んに最初受器の温度低き間は媒助娈は脂肪酸を溶解して疑縮せる水層の上にあれ ごす温度の上昇して $97-99^{\circ} \mathrm{C}$ に到れば水蒸汽に件はれて第一受器よる溜出する が故に冷却器を用ひて第2の受器 $\mathrm{F}$ に導く時は損出する事無く媒助斉はF中に 於て水層上に回收する占得るが故は反復使用する事を得心し又脂肪酸は第一の受

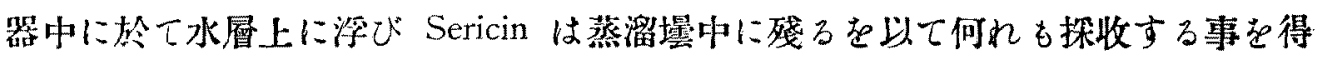
ベし本方法により數種の純脂肪酸に就き蒸溜温度を測定し過熱水蒸汽のみの場合 に於ける蒸溜温度され比軴せるに次の如き結果る得たり 
脂肪酸 $の$ 種類

Stearic acid

Palmitic "

Oleic $" \prime$

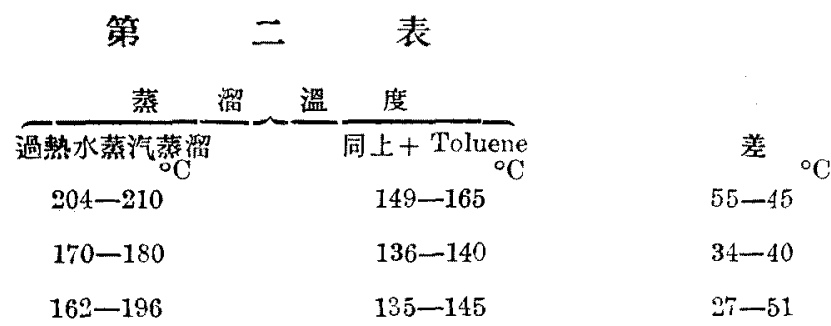

本成績に徵すれば Superheated steamのみを用ひて Distillation 篇す場合に比 し蒸溜媒助劑さして Toluene を使用せる場合は的 $30^{\circ} \mathrm{C}$ 万至 $50^{\circ} \mathrm{C}$ 內外の蒸溜 温度の低下するを見たり

今文献 場合並びに水蒸氣を通じて蒸溜せる場合の蒸溜温度は次表に示す如し

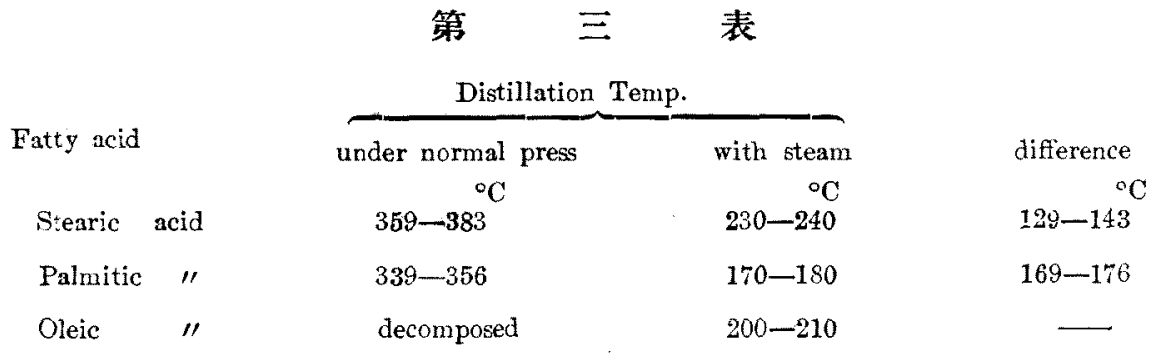

本表に依れば 3 種の脂肪酸の蒸溜に當り水蒸汽を使用する時は之き使用せざる 場合に比して $129^{\circ} \mathrm{C}-176^{\circ} \mathrm{C}$ 蒸溜温度の低下するを見る[本表のStean distillation に依る蒸溜温度こ余輩の實驗に依る（第二表）結果さを此較すれば Palmitic acid のものは全然一致し居れミも其他の二者は可なり相違あり之れ交献に於ける Steam の温度さ余の實驗のSteam の温度及供試品の純度の相違に基くものなる心 L]

如斯く脂肪酸の蒸溜に當り Steam を使用する時は其の蒸溜温度菓低下し更に

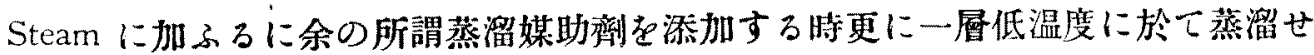
らるつは何故なるや換言すれば Steam distillationの原理は如何こ云ふに之れ全く Dalton氏の死斯體の壓力に關する法則を以て證明せらるぺし

Dalton 氏の法則は ${ }^{(28)}$

「一定の温度にて數種の氣體が相混じて生ずる混合䓙體の壓は之を組成せる氣 體が混合鮙體さ同容にて呈する壓の和に等し」 
換言すれば混合妞體を組成する各氮體は他の氣體の影響なく各自の壓力を呈す るこ云ふ意義なり

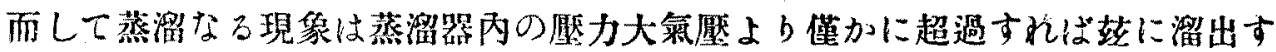

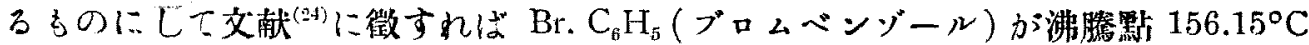
なるに拘らす之を Steam こ共に Distillation を行ふ時は $95.25^{\circ} \mathrm{C}$ より僅かに高 温度に於て蘶溜せらるこ云ふ

\begin{tabular}{lccc} 
& \multicolumn{1}{c}{ 第 } & 四 & 表 \\
Temp & $\begin{array}{c}\text { Vapnurpress. of } \\
\text { Br. } \mathbf{C}_{6} \mathrm{H}_{5}\end{array}$ & $\begin{array}{c}\text { Vapour press.of } \\
\mathbf{H}_{2} \mathrm{O}\end{array}$ & Sum \\
$95^{\circ} \mathrm{C} ;$ & 120 & $634 . \mathrm{m}$. & $\mathbf{m} . \mathrm{m}$. \\
95.25 & 121 & 639 & 754 \\
96 & 124 & 657 & 760
\end{tabular}

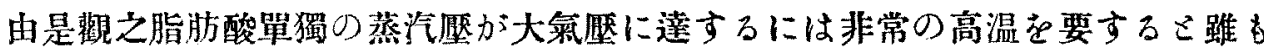
水蒸汽㻺立びに蒸溜媒助劑の蒸汽壓が加はる時は遥加に低温度に於て之等の合計 の厴は大氯壓に達するを以て該低溫度に於て脂肪酸は溜出せらるっなら

本方法に依り蒸溜を行ふ時は脂肪酸の $90 \%$ は溜出せられ殘艅の $10 \%$ Sericin こ混じて蒸溜器に止る

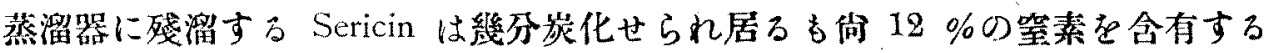
を以て肥料製造の原料さなし得べし

本研究に際し絹業訊羷所技手尾川岸太君同助手門庫定信君の助力に待つ所芕し 慈に特筆して深厚なる謝意を表す

\section{概 括}

1. 石簽に依る絹精練の廢液は絹の染色に際して助劑こして一部利用せらるれご

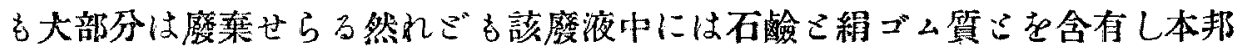
輸出絹物のみの精練より出る廢液にても之回收せば年額數十万圓の價值す ろべし

2. 精練廢液の利用方法方研究せられ始めたるは 19 世紀の終末に於引る 10 年 問以降にして絹精練の歷史の古きに比すれ标極めて最近の事に屬す

3. 精練廢液利用の問題は工業的に實施せられたるるの無さにあらず踓も多い は一時的のものにして或は技術的の困難に㑈り或は經濟的不引合の篇め中止 の止さ黙なきに到れるるの多し 


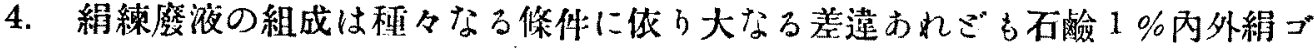
ム質 0.5 - 1 \%遊離脂肪酸 $0.1 \%$ 内外にして回收の目的物たり得るものは脂 肪酸さ絹ゴム質（Sericin）の外に出でず

5. 精練黁液利用の力法に關する從桃の方法は次の三種に分類する很得にし即ち

(a) 脂肪酸を回收して石瞼に還元せんさするもの

(b) Sericin巳脂肪酸さを分離し前者は之を肥料に後者は之る石畧になさん そするもの

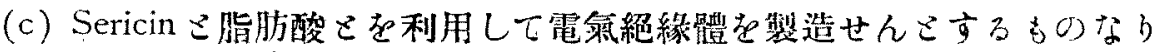

6. 交献に表はれたる方法につき筫驗的に其比較を試みたるに (a) 值接强酸にて

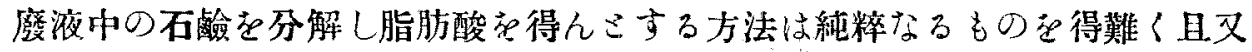
分嵟の作業も容易にあらす

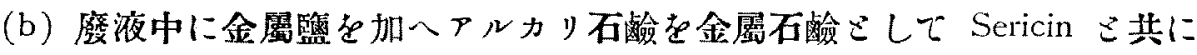
沈澱せしめ母液より分離せる後温湯，稀薄なるアルカリ或は加壓熱湯 等にて Sericin を溶解して以て金屬石㽟と分離し Sericin は酸にて沈 澱せしめ又金屬石鹼をば分解して脂肪酸走得んこする方法は Sericin の分離か;完全には行は好ざるを以て脂肪酸も亦純粹なるものる得る事 能はず且 Sericin 水溶液より酸にて析出せしむる事嚾し

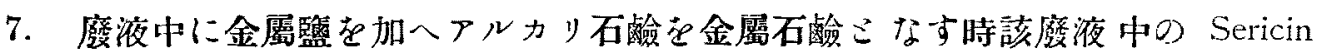

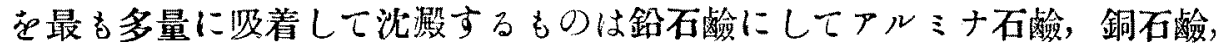
石灰石醶等之に亞ぐ

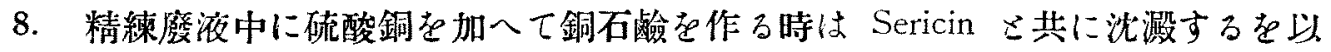
て母液より分離し之にロート油，加里石鹼，アラビヤゴム，ビラチン等を加 一て乳化する時は殺菌劑を生成せしむる事を得へしし(25)

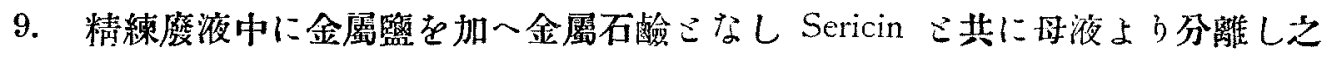

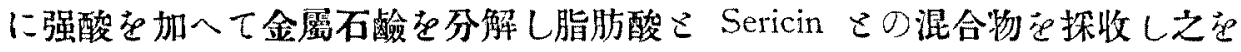
蒸溜嚗に入れ過熱水蒸汽こ蒸溜媒助劑已在利用して水蒸汽蒸溜を行ふ時は單 に水蒸汽のみを以て蒝溜する場合に比し遙かに低さ温度に於て苲溜せしめ得

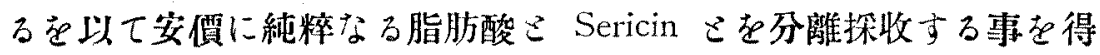

參考文献

(1) Silk, May, 1924, Raff aele Sanson : Recovery and Ltilization of Old Silk Degumming Baths. 
(2) 帝國特許第38360躆

(3) Textilberichte (Auslandsheft) Vol, VI, Nr. IX, 1925.

(4) Silbermann, Die Seide, Band, II. S. 252

(5) 同上

(6) 同上

(7) Taylor: English Patent. No. 6331,

$\left(7^{\prime}\right)$ Ind. and Eeg. Chem. Vol. 7, No. 8 (1925)

(8) 帝國特部第38360號

(9) (1) 已同し

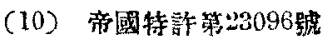

(11) Textilberichte, V. Jahrgang, April Nr. 4 (1624)

(19) 西田博太郎著近世色染法. 第二編 P. 272

（13）帝國特部第63906號

（14）理化學听究所胥報第二輯第三號 p. 302

(15) Silbermann; Die Seide Band, II S. 251

(16) (1) 巳同し

(17) (11) ¿同已

(18) Colour Trade Jour, and Testile Chemists. Vol. XV No. 5

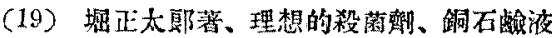

(20) Lewkowitsch: Chemical Technologyand Analyis of Oils Fats and Waxes. Vol. III p. 113,

- p. 115. p. 267. p372.

(21) Lewkowitsch : Vol. 1 p. 90 ; 及Jour. Amer. Chem Soc, 1900, 22.

（22）田中、喜多共編 有機犁造工業化學上卷 p.p.187-188

（23）片山正夫氐著 化學本論，p.p.181-192

(24) Gatterman; Die Praxis des Organischen Chemikers. p.p. 35-36

(25) 帝國特許 第65055號 